\title{
Weights and Measures, Currency, Orthography, and Fiscal and Calendar Years
}

\section{Weights and Measures}

The following list shows the principal Brazilian weights and measures and their closest metric equivalents.

I alqueire $=36.27$ liters (roughly one English bushel)

I arroba $=\mathrm{I} 4.746$ kilograms

I braça $=2.2$ meters

I légua (league)= between 5,555 and 6,666 meters

I tarefa $=$ an area of 30 braças by 30 braças $(4,356$ square meters $)$, or roughly one acre

\section{Currency}

Both before and after independence, the basic unit of currency in Brazil was the real (réis in the plural), which existed only as a money of account. The sum of Ioo réis was commonly written Rs.\$ Ioo. Larger sums were calculated in mil-réis (literally one thousand réis), with one mil-réis written as Rs.I\$ooo. One thousand mil-réis equaled one conto de réis /or simply one conto), written Rs.I:000\$000 or Rs.I:000\$. Thus, a sum of Rs.4:563\$000 should be read as 4 contos 563 mil-réis, and Rs. I\$320 as I,320 réis. 


\section{Orthography}

Not until the early I940s did a single, standardized orthography for the Portuguese language come into use in Brazil. This text follows the rules of the most recent standardization for spelling Portuguese words, the names of places and persons, and other proper nouns. It does, however, retain a few older spellings of proper nouns where these remain today in widespread use (for example, Góes, Souza, Maragogipe, and São Felipe for Góis, Sousa, Maragojipe, and São Filipe, respectively). In citing manuscript materials in the notes, the spellings of correspondents' names have been modernized; but the titles of documents have been transcribed as they appear in the documents. Similarly, following convention, author-title information for older published works is cited as it appears on the title page.

\section{Fiscal and Calendar Years}

At least from I 817 on, accounts for the export trade at Bahia were opened annually on I October and closed on 30 September of the following year. Sources, as a result, sometimes provide information on exports in fiscal years (for example, I 853-54). Wherever necessary in the tables and figures, fiscal years have been "converted" to calendar years, using, for example, I854 rather than I 853-54. This conversion makes it easier to present data graphically in the figures and facilitates comparisons with series based on calendar years (for example, the exchange rate of the mil-réis). 